\title{
THE EFFECTIVENESS OF COMMUNICATIVE APPROACH IN TEACHING THE SIMPLE PAST TENSE AT SMPN 12 BATAM
}

\author{
Suswanto Ismadi Megah S. ${ }^{1}$, Dede Afifah ${ }^{2}$ \\ University of Riau Kepulauan \\ I'megah76@yahoo.co.id,2'dede.afifah@gmail.com
}

\begin{abstract}
This study was aimed to identify $t$ The Effectiveness of Using Communicative Approach in Teaching the Simple Past Tense. This research employed quantitative research method. The design of the collecting the data that used in research are, questioner method, test method in carrying out this research. This research was conducted at class of second year students of SMPN 12 Batam in the academic year 2018/2019. As for the time the researched held on 31 March 2019 until 25 May 2019. In this research, the populations of the study were students in second year students at SMPN 12 Batam in the academic year 2018/2019. There were students from two classes, whereas the samples are 62 students, where 30 students from class VIII-4 (control class) and 32 students from VIII-5 ( the experiment class). This research was concluded that the effectiveness of using communicative approach in teaching the simple past tense: A case study of second year students at SMPN 12 BATAM in the academic years 2018/2019. The result was the calculation of the t-test, it was obtained that the t-observed was 5.506 and $t$-table was 2.042 at the level of significant 0,05 . It was obtaining that $t$-observed $>t$-table, it means the alternative hypothesis $(\mathrm{Ha})$ was accepted and Ho rejected.
\end{abstract}

Keywords: Effectiveness, Teaching Approach, and simple Past Tense

\section{INTRODUCTION}

Language is means of communication among individuals. It is a system of sounds which is structured and is used to communicate people's feelings, intentions, purpose, etc to the others. It is a special characteristic of human or it can also be regarded as one of human criteria, because only human beings speak a language. Nevertheless, the ability to speak a language should be developed in a social group.

English became internationally-official language in international forum since the end of the Second World War; English become the most widely used as international language. Habbieb (2017) More people are trying to learn English than any other language in the world. In Indonesia, English is taught since at elementary school in some areas for instance Batam as local content to universities as general course. So it can be an important subject for the school or the college. English as a foreign language in 
Indonesia, this must be taught for every learner because it has also been an important part of curriculums.

Ministry of Education of the Republic of Indonesia considers that its people need to have the competence in using this language. The States Policy (GBHN) 1999-2004 put foreign language in a very important position in national education context. Taken from (http//:epository.upi.edu.ing.397.pdf) (download on February 6, 2019). Approaches and methods of teaching and learning English in Indonesian schools, particularly in junior and senior high school level, have evolved and developed through time.

The Indonesian government has done many efforts to make the English teaching and learning in these levels of school more effective. The curriculum makers, hand in hand with teachers, have tried to find the best ways to teach this language to the students to get the best learning outcome. The curriculum has been changed and teachers are upgraded with up-to-date methods and best practices on how to teach the language in the classroom effectively.

English is studied as their compulsory subject to learn in the formal schools starting from their first year of junior high school. However, in certain areas such as in big cities, many of them have even been familiar to this language since they are in their elementary schools. Those schools have included English in their curriculum as the local content to teach to the students. The 2006 English curriculum, the curriculum suggested by the government, states that the main target of English language learning for the students of junior high school is to have the discourse competence; the ability to communicate both in oral or written language in a communication event .

The curriculum further elaborates that to reach this competence needs the support of several competences, namely: the socio-cultural competence, the linguistic competence, the actionable competence, and the strategic competence. The sociocultural competence refers to the ability to convey messages appropriately according to the cultural contexts where and when the communication happens.

In English lesson, they are many skills should be dominate by the student to mastery the four basic language; the skills are listening, reading, speaking, and writing. 
Besides the four skills, they also have to master grammar properly. Grammar should be taught appropriately because it's the basic element of the language without the proper knowledge of grammar; the learners will find many problems to build up sentences to express their ideas in communication among the people. As stated by Awang (2014:6) Teaching English as a foreign language (TEFL) requires learners"e exposure to what is called the foreign language skills.

In talking about grammar, one of the most important parts to be learning is "tenses". "Tenses are usually defined as relating to the time of an action, event or state." Taken from (http://books.google.co.id/books/ about/english_word_foundation). (Download on February 4th 2019). By tense, the students can know what time the action occur, and understand correspondence between the form of the verb and their concept of time, for example, the form of simple past tense ( $\mathrm{S}+\mathrm{V}-2)$ is easy to remember but the student are lazy to memorize V-2. Some students think of grammar as rather boring subject. When they learn English, they try to avoid the grammar that is confusing and hard to be understood. Harry Howard Gilbert (1931) Survey found that high school students were more likely to attribute their failing performance to laziness, while teachers ranked "lack of skill" as the major cause, with laziness coming in second.

To cover the entire problem, to in order the student not to be bored, the communicative approach is used. Because communicative approach demands the students to be active and creative. So that learning process is not boring. It is humanistic, because it concern with the students activities in real situations and has making in content or function of language.

According to Awang (2014) supports the teaching-learning process to run more effectively and efficiently. In language teaching, communicative approach means "An Approach which views language as a form of social behavior and sees aim of language teaching as teaching learners to communicative fluently, appropriately, and spontaneously in the cultural context of the target language." (http://www.bookdepository.co.uk/Introduction-Language-Language-Teaching-CJBrumfit/) (Download on February 2nd 2019). 
Furthermore, Zaini et. al. (2008) explains that there are many methods and approaches are designed by experts of language method appear to be based on very different views of what language is and the how language is learned. Communicative approaches is approach which designed by the experts of language.

The simple past tense as a part of grammar rules sometimes also make students confusing. The effect is the students can not use and understand properly the simple past tense. So it needs an interesting approach that can give the motivation by using communicative approach.

\section{Communicative Approach}

The communicative approach to language teaching can be regarded of concept or idea underlying the assumption that language is used for communication, so, in designing material it should concede with the communicative function of language. According to Savignon (1983: 8), he says that communication is also defined as a continued process of expression, interpretation and negotiation. The term communicative approach has the same meaning as the term notional and functional. Meanwhile, Cameron (2001: 40) says that speaking is the active use of language to express meanings so that other people can understand them. It means that speaking is a productive skill that involves an active interaction between the speaker and listener to deliver meanings or information . According to Nunan (1989: 32), the successful oral communication involves.

It concludes that communicative approach only emphasizes communicative competence in language learning by using interaction and communication in natural situation. Language is a means of communication. What is communicated are meaning and messages. These meaning and messages are continuing by the situation of communication. In language teaching, the language form must always be linked to their meaning as they are defined by the context and situation, and they must be presented as meaning carriers. In short, language form must be presented with their meaning. Communicative approach is an approach to learn language based on communicative competence.

\section{Grammar}

Talking about the definition of grammar, there would probably be as many definitions as the number of linguistics who manages to define it. Those definitions, however, 
essentially convey the same idea Cook and Suter (1980:1) state: "Grammar is a set of rules by which people speak or write. These rules are not always understood consciously, and if you asked people what the rules of English grammar were, they would probably offer one or two or say they did not know. According to Cook and Suter, (1980:1) the reason is that the rules we refer to are those that hardly anyone ever thinks about but which allow people to use their language easily and naturally most of the time". The statement indicates that grammar is a set of rules derived from a language; rules that most of its native speakers rarely care about. However, these enable them to communicate each other without creating misunderstanding and misinterpretation. They commonly do not realize that when they express themselves through writing and speaking, what they write or speak have patterns and they keep subconsciously applying the patterns in their communication. Meanwhile, Cameron (2001: 40) says that speaking is the active use of language to express meanings so that other people can understand them.It means that speaking is a productive skill that involves an active interaction between the speaker and listener to deliver meanings or information. Then, Nunan (1989: 32) adds that the successful oral communication involves.

Bowers and Brumfit (1991:47) say that "grammar is a language" It means if students learn a language, they will also learn the grammar of the language. Thus, learning grammar becomes an inseparable part of language and becomes an important aspect if the students want to speak and write English well.

The simple past tense, according to Danesi (2006:139) in Basic American Grammar and Usage stated that, the simple past tense also known as the preterit, allows you to refer to actions that occurred in the past without reference to the present. It is used to talk about actions that happened at a specific time in the past. State when it happened using a time adverb. Form the simple past of a verb by adding -ed on to the end of a regular verb but, irregular verb forms have to be learned. (http://www. grammarly.com/handbook/grammar/verbs/9/simple-past-tense)(Download on February 20th 2019). 


\section{METHODOLOGY}

In this research, the writers has some steps in doing this research. We should know first what research we want to do and how to develop that data, based on the data that we collect. According to Hariwijaya and Djaelai ( 2004:41-45) the design of the collecting the data that used in research are, questioner method, test method, library method, observation method and interview method. In this final task the writer choose two method of collecting the data they are : the library method and questioner method for this research. This research is conducted at class of second year students of SMPN 12 Batam in the academic year 2018/2019. As for the time the researched held on 31 March 2019 until 25 May 2019. In this research, the populations of the study are students in second year students at SMPN 12 Batam in the academic year 2018/2019. There are students from two classes, whereas the samples are 62 students, where 30 students from class VIII-4 (control class) and 32 students from VIII-5 ( the experiment class).

\section{RESULT AND DISCUSSION}

\section{Result}

The Total Number of the students who belong to the Experimental group in this research were 38 student. The data show that the higest score of Eksperimental group was 100.00 and the lowest 70.00. The data gave information that mean of the score was 86.31 and the standart deviation was 10.80 .

Interpretation of the Data

In this chapter the writers would like to present the description of the data obtained. The population of the study was second year students of SMPN 12 Batam in academic year $2018 / 2019$. 
Table 1. Normality Test (Control Group and Experimental group) One Sample Kolmogorov-Smirnov Test

\begin{tabular}{llrr}
\hline & & EG & CG \\
\hline $\mathrm{N}$ & & 38 & 38 \\
Normal & Mean & 72.894 & 86.315 \\
Parameters & Std. Deviation & 10.438 & 10.823 \\
& Absolute & .173 & .186 \\
Most Extreme & Positive & .136 & .171 \\
Differences & Negative & -.173 & -.186 \\
& & & \\
& & 1.067 & 1.146 \\
Kolmogorov-Smirnov Z & .205 & .145 \\
Asymp. Sig. (2-tailed) & & \\
\hline
\end{tabular}

Kolmogorov-Smirnov $\mathrm{Z}$ is a number generated from the Kolmogorov Smirnov techniques to test the suitability of our data distribution with a certain distribution, in this case the normal distribution. This number is usually written in the research report when discussing the normality test. Asymp. Sig. (2-tailed) is the value resulting from hypothesis testing. If the value of $\mathrm{p}$ greater than 0,05 , then the conclusion drawn is that we test the data distribution follows a normal distribution. According the table above the data of control group and experimental group were normal .It were because the result of Asymp. Sig. (2-tailed) is higher than 0, 05. They were $0.145>0,05$ (Experimental Group) and 0.205> 0, 05 (Control Group).

Hypothesis Test

To ensure the t- test was accurate writer used SPSS 16.0 program. The result t-test as below: 
ANGLO-SAXON, VOL. 10, NO.2 : 264-274

Desember 2019

P-ISSN 2301-5292

E-ISSN 2598-9995

Table 2. T-Test (Control group and Experimental Group)

Paired sample Test

\begin{tabular}{|c|c|c|c|c|c|c|c|c|c|}
\hline & & \multicolumn{5}{|c|}{ Paired Differences } & \multirow[b]{5}{*}{$\mathrm{t}$} & \multirow[b]{5}{*}{ Df } & \multirow{5}{*}{$\begin{array}{l}\text { Sig. } \\
(2- \\
\text { tailed) }\end{array}$} \\
\hline & & \multirow[b]{4}{*}{ Mean } & \multicolumn{4}{|c|}{ 95\% Confidence } & & & \\
\hline & & & \multirow{3}{*}{$\begin{array}{c}\text { Std. } \\
\text { Deviati } \\
\text { on }\end{array}$} & \multirow{3}{*}{$\begin{array}{l}\text { Std. } \\
\text { Error } \\
\text { Mean }\end{array}$} & \multirow{2}{*}{\multicolumn{2}{|c|}{$\begin{array}{c}\text { Interval of the } \\
\text { Difference }\end{array}$}} & & & \\
\hline & & & & & & & & & \\
\hline & & & & & Lower & Upper & & & \\
\hline Pai & E_Grou & 13.421 & 15.027 & 2.437 & 8.481 & 18.360 & 5.50 & 37 & .000 \\
\hline r 1 & $\mathrm{p}-$ & & & & & & 6 & & \\
\hline & C_Grou & & & & & & & & \\
\hline & $\mathrm{p}$ & & & & & & & & \\
\hline
\end{tabular}

Based on the calculation of the t-test, it was obtained that the t-observed was 5.506 and t-table was 2.042 at the level of significant 0,05 . It was obtaining that $t-$ observed > t-table, it means the alternative hypothesis (Ha) was accepted and Ho rejected. In other word, using communicative approach give a significant effect in teaching the simple past tense.

\section{DISCUSSION.}

In the research, pretest and posttest were given to both control and experimental groups in order to find out whether or not the cooperative learning communicative language teaching technique improved student's speaking ability. According to the previous explanation, there were positive result in this study that were in line with the theories.

According to Brown (2001:9) states that speaking is an interactive process of conducting meaning that involves producing, receiving and processing information, the process of the cooperative learning: communicative language teaching had facilitated students to produce. Receive and process information. It was also 
appropriate with Nunan (1991:12) stated that success is measured in terms of the ability to carry out a conversation in the target language.

In addition, base on Brown (2001:16) stated that students also stated that this kind of technique should be frequently implemented in the learning process so that they could be accustomed to speaking English because speaking is truly basic skill in language learning - speaking is used twice as often as listening and the most often used skill inside the classroom.

It showed that the process is also compatible cooperative learning techniques promote student learning and academic achievement, increase student retention, enhance student satisfaction with their learning experience, help students develop skill in oral communication, develop students' social skill, promote student self esteem, and help to promote positive race relations.

However, according to Brown (2001: 25) states that some other factors existed in the process of pre and posttest, for example, students' condition at the time test was administered. Some of them felt sleepy, sick, or in a bad mood. Other students felt stressed because there was homework they had not finished yet. Some was depressed because they were not ready for another subject's test after English subject at that day. Such factors influenced students' speaking performance. Their self confidence to speak decreased. It was in line with the affective principle that language ego. Self confidence, risk taking, and language culture connection influence the learning. As a result, some students got high score on the pretest, but lower on the posttest.

After transcribing the interview result, it could be interpreted that the cooperative learning Communicative language teaching technique made the learning process fun and interesting, gave a greater chance for students to socialize, students were motivated to master materials, and students thought that it had something different in the learning process. It was in line with the Vygotsky's statement stating that learning is mediated by social interaction. Communicative language teaching facilitated this kind of social interactions among students. It awakens a variety of 
internal development processes are able to operate when the child is interacting with people in his environment and in cooperation with his peer.

At the end of the session of the cooperative learning communicative language teaching technique, the student stated that their speaking skills improved although the improvement was small. Their mostly appeared problem were that their vocabulary and pronunciation. To handle such problems, they usually asked their dictionary to find the definition of difficult words or phrases.

Some of them suggested different things. They wanted the material was not limited and they could be determined their materials themselves. The other said that they needed other techniques that could facilitate them to obtain another skill, for example writing skill.

Based on the discussion above, it could be seen that the cooperative learning communicative language teaching technique was generally effective in improving the students' speaking ability because it increased the students' achievement in speaking ability covering fluency, grammar, vocabulary, and pronunciation. Concluding the questionnaire and interview results, the technique was also well appreciated by the students

\section{CONCLUSION}

This research can be concluded that the effectiveness of using communicative approach in teaching the simple past tense: A case study of second year students at SMPN 12 BATAM in the academic years 2018/2019. 
ANGLO-SAXON, VOL. 10, NO.2 : 264-274

Desember 2019

P-ISSN 2301-5292

E-ISSN 2598-9995

Based on the calculation of the t-test, it was obtained that the t-observed was 5.506 and t-table was 2.042 at the level of significant 0,05 . It was obtaining that $t-$ observed > t-table, it means the alternative hypothesis (Ha) was accepted and Ho rejected.

\section{REFERENCES}

Awang, Hidiaka Febriansyah.2014.Efforts To Improve Classroom Interaction In English Teaching-Learning Process Through Communicative Tasks to the 8th Grade Students of SMPN 3 Wates. Yogyakarta:UNY Tesis.

Bowers, Roger and Chistoper Brumfit 1991. Applied Linguistics and English Linguistics and English Language Teaching. London: Macmillan Publisher Limited.

Brown, H.D. 2001. Teaching by Principles: An Interactive Approach to Language Pedagogy (2ndEd). New York: Longman.

Cook, S and R. Suter. 1980. The Scope of Grammar: A Study of Modern English. Mishawaka: McGraw-Hill Companies.

Danesi, Marcel 2.006. Basic American Grammar and Usage. New York: Barron's Educational Series, Inc.

Habeeb, Ahmed. 2017. How English Became The Global Language. Mansouria:Researchgate.

Nunan, D. 1989. Designing Tasks for the Communicative Classroom. Cambridge: Cambridge University Press.

Rivers, W.M. 1987. Interactive Language Teaching. Cambridge: Cambridge University Press

Savignon, S.J. 2002. Interpreting Communicative Language Teaching: Contexts and Concerns in Teacher Education. New Haven \& London: Yale University Press

Zaini et. al.. 2008. Strategi Pembelajaran Aktif. Yogyakarta: Pustaka Intan Madani. 